\title{
Mutations affecting interaction of integrase with TNPO3 do not prevent HIV-1 CDNA nuclear import
}

\author{
Alexandra Cribier ${ }^{1,2,3}$, Emmanuel Ségéral ${ }^{1,2,3}$, Olivier Delelis ${ }^{4}$, Vincent Parissi ${ }^{5}$, Aurélie Simon ${ }^{1,2,3}$, Marc Ruff ${ }^{6}$, \\ Richard Benarous ${ }^{7}$ and Stéphane Emiliani ${ }^{1,2,3^{*}}$
}

\begin{abstract}
Background: Integration of human immunodeficiency virus type 1 (HIV-1) into a host cell chromosome is an essential step under the control of the viral integrase (IN). Although this enzyme is necessary and sufficient to catalyze the integration reaction in vitro, cellular cofactors are involved in the process in vivo. The chromatinassociated factor LEDGF/p75 interacts with IN and promotes integration to transcription units of the host genome. HIV-1 IN also binds the karyopherin TNPO3, however the significance of this interaction during viral replication remains to be explored.

Results: Here we present a functional analysis of IN mutants impaired for LEDGF/p75 and TNPO3 interaction. Among them, IN W131A and IN Q168L, that were previously identified to be deficient for LEDGF/p75 interaction, were also partially impaired for TNPO3 binding. We observed that mutations abolishing IN ability to form tetramers resulted in a severe reduction in LEDGF/p75 binding. In sharp contrast, no correlation could be found between the ability of IN to multimerize and TNPO3 interaction. Most of the mutant viruses were essentially impaired for the integration step whereas the amount of 2-LTR circles, reflecting the nuclear import of the viral DNA, was not significantly affected.
\end{abstract}

Conclusion: Our functional analysis of HIV-1 IN mutants reveals distinct structural basis for TNPO3 interaction and suggests that the interaction between IN and TNPO3 is not a major determinant of nuclear import but could take place at a nuclear step prior to integration.

\section{Background}

Following the entry of the HIV-1 viral core into the cytoplasm of a target cell, reverse transcription of the retroviral RNA into a linear double strand cDNA copy takes place within the reverse transcription complex (RTC) $[1,2]$. Once synthesized by the RTC, this viral cDNA becomes part of a large nucleoprotein complex called the pre-integration complex (PIC) [3-5]. HIV-1 PICs retain components of the RTC: nucleocapsid (NC), integrase (IN), matrix (MA), $\mathrm{Vpr}$ and reverse transcriptase (RT) $[3,6]$, together with cellular cofactors. This complex is transported to the nucleus where the viral cDNA integrates into a host cell chromosome, a key

\footnotetext{
* Correspondence: stephane.emiliani@inserm.fr

${ }^{1}$ Inserm, U1016, Institut Cochin, Paris, France

Full list of author information is available at the end of the article
}

step that is under the control of the retroviral enzyme IN [7-9]. Whereas the recombinant HIV-1 IN protein is sufficient to catalyze the 3 ' processing and strand transfer activities for in vitro integration, functional interactions between IN and host cell factors are required during the early events of HIV-1 replication in vivo [10-12].

HIV-1 host cell factor dependency is well illustrated by LEDGF/p75, a cellular chromatin-associated protein involved in transcriptional regulation of cellular genes that were identified as an IN interacting factor $[11,13,14]$. LEDGF/p75 plays an important role in lentiviral cDNA integration, as demonstrated by mutagenesis [14-17], over-expression of LEDGF/p75 IBD (Integrase Binding Domain) $[18,19]$, as well as RNAi and knockout studies [18-23]. Structural studies revealed the roles of both the catalytic core domain (CCD) dimeric

\section{Biomed Central}

(c) 2011 Cribier et al; licensee BioMed Central Ltd. This is an Open Access article distributed under the terms of the Creative Commons Attribution License (http://creativecommons.org/licenses/by/2.0), which permits unrestricted use, distribution, and reproduction in any medium, provided the original work is properly cited. 
interface as well as the N-terminal domain (NTD) of IN for high affinity binding to IBD $[16,24,25]$. In addition, LEDGF/p75 stimulates the formation of IN tetramers, which are required for efficient concerted integration of both viral ends into host DNA [26-29]. Furthermore, the targeting of viral integration to specific regions of the host chromosome is under the control of LEDGF/ p75. Indeed, LEDGF/p75 guides the site selection of lentiviral integration within transcription units (TUs) of transcriptionally active genes, while $\mathrm{GpC}$ islands and promoter regions are disfavored [20,21,30]. Albeit not strictly essential for replication, LEDGF/p75 tethers PIC-associated IN to chromatin to presumably stimulate its enzymatic activity at the site of integration [31,32].

In contrast to the gammaretrovirus Moloney murine Leukemia Virus (MLV), HIV-1 and other lentiviruses possess the ability to infect both dividing and non-dividing cells $[33,34]$. This specificity is particularly important to explain the infection of terminally differentiated cells, including macrophages and microglia that constitute an important reservoir of virus in infected individuals [35]. In these cells, the mechanisms leading to the establishment of an integrated provirus are still unclear. One key step could be the nuclear import of the PIC, which must be translocated through the intact nuclear membrane in an energy dependent manner. To pass through the nuclear pore complex (NPC), components of the PIC must interact with cellular nucleo-cytoplasmic transport factors as well as NPC components such as nucleoporins (NUPs). Several viral determinants, including karyophilic signals of MA, Vpr or IN, as well as the viral flap DNA structure could contribute to the nuclear import of the PIC; however, their exact role is still debated (see [36-38] for recent reviews). In contrast, CA recently emerged to be a key factor in conferring the ability of HIV-1 to infect non-dividing cells. While evidence of a direct interaction between CA and the nuclear import machinery is still lacking, CA uncoating of the core appears to be coupled with an active nuclear translocation [39-41]. CA dissociation could allow subsequent interactions of viral karyophilic motifs with nuclear import factors. Alternatively, it was observed that intact capsid lattices remain associated with the PIC and that uncoating of the core occurs at the nuclear pore upon completion of the reverse transcription [42].

The cellular factors involved in PIC nuclear import have been the focus of numerous and often contradictory studies. Members of the importin $\alpha$ protein family were previously shown to interact with IN [43-50]. Importin 7, a nucleocytoplasmic factor related to importin $\beta$, was also implicated in this process by directly interacting with IN $[48,51,52]$. In addition to karyopherins, several components of the nuclear pore complex
(NPC) were identified to play a role in early steps of HIV-1 replication [53-57].

Using genome-wide RNAi knock down approaches, TNPO3 was recently identified as a HIV-dependency factor involved at a stage between reverse transcription and integration $[53,55]$. TNPO3 belongs to the importin $\beta$ family that plays the role of transporter of serine/arginine rich (SR) proteins into the nucleus [58-61]. TNPO3 was shown to mediate nuclear import of the PIC, both in dividing and non-dividing cells [62]. We identified TNPO3 as a partner of IN by yeast two-hybrid ( $\mathrm{y} 2 \mathrm{H})$ screenings using IN as a bait, and rebound screenings using an HIV-1 library confirmed that TNPO3 interacts solely with IN $[62,63]$. Whereas a direct interaction between HIV-1 IN and TNPO3 was confirmed by different studies [62-64], its relevance in HIV-1 replication has been questioned. For instance, no correlation could be found between the affinity of TNPO3 for different retroviral INs and its requirement during infection $[64,65]$. Instead, studies pinpointed to a dominant role of CA for TNPO3 dependency $[64,66]$.

Here, we assessed the role of TNPO3-IN interaction in $\mathrm{HIV}-1$ replication. Site-directed mutagenized IN proteins were analyzed for LEDGF/p75 and TNPO3 interaction. The structure function analysis of these mutants revealed that mutations previously characterized to impair LEDGF/p75 binding also affected interaction with TNPO3. However, contrary to what was observed for LEDGF/p75, TNPO3 binds IN regardless to its tetrameric state. Importantly, while impairing HIV-1 replication, none of these mutations significantly affected amounts of 2-LTR circles, indicating a lack of correlation between the ability of IN to interact with TNPO3 and nuclear import of HIV-1.

\section{Results}

Recent retroviral intasome structures revealed a tetramer of IN formed by a dimer-of-dimers $[28,67]$. To characterize whether the tetramerization of HIV-1 IN was involved in TNPO3 interaction, we analyzed mutants of IN that are affected in their abilities to multimerize. Residues Lys188 and Tyr194 within the CCD of IN are located within a loop connecting CCD helices $\alpha 5$ and $\alpha 6$ involved in tetramerization [26] (Figure 1A). Lys188 forms a salt bridge with Asp25 at the intermolecular NTD-CCD interface, while Tyr194 is involved in the hydrophobic interaction at the dimer-dimer interface $[26,27]$ (Figure 1B). Alongside these residues, we also included in our assays two previously characterized IN mutants W131A and Q168L that were deficient for LEDGF/p75 binding [14,15,17]. The residue Q168 does not interact directly with LEDGF/p75, but hydrogenbond with W132 from the opposite IN monomer, 

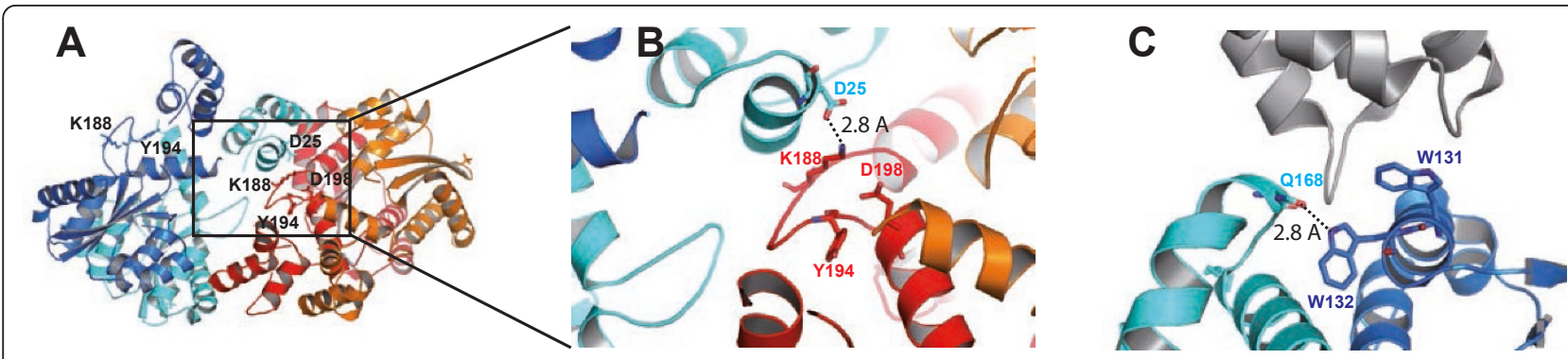

Figure 1 HIV-1 integrase mutants. (A) Crystal structure of an IN subunits of IN are colored blue, cyan, red, and gold. (B) At the NTD-CCD interface, the $\varepsilon$-amine of Lys188 is located at $2.8 \AA$ from Asp25 making and H-bond and at $4.5 \AA$ from Glu198 (also indicated). (C) IN $\mathrm{N}_{C C D}$ LEDGF/P75 $5_{\mathrm{IBD}}$ interface (PDB ID 2b4j, [24]). Individual subunits of IN are colored in blue and cyan, LEDGF/P75 $1 \mathrm{BD}$ is colored in grey.

therefore participating in the dimerization of IN (Figure 1C). The residue W131 is directly involved in hydrophobic contacts with LEDGF/p75 residues F406 and V408 [16,24-26].

Purified HIV-1 IN exists in solution as a mixture of multiple oligomerized forms containing monomers, dimers and tetramers, even in absence of DNA. We used size exclusion chromatography (SEC) to assess the multiple multimeric states of our tag-free IN mutants. In this assay, wild type IN was predominantly tetrameric, with the presence of two smaller peaks corresponding to the dimeric and monomeric forms. IN W131A behaved mostly as a mixture of tetramers and dimers. In sharp contrast, mutation Q168L disrupting the Q168-W132 H-bond results in a major shift to a low molecular weight peak corresponding exclusively to monomers. Substitution of the Lys188 residue to a Gln, targeting the Asp25:Lys188 intra-molecular salt bridge, also led to a monomeric form of IN. A recent crystal structure of IN tetramers pinpointed a role of residue Tyr194 in the closure of the dimer-dimer interface [26]. Substitution of Tyr194 by hydrophobic residue Phe resulted in an elution profile similar to wild type IN. Remarkably, mutation Y194E led to a pronounced shift to monomeric forms. These results are in good agreement with previous reports highlighting a role of the 186-195 loop in the tetramerization of IN [26,27] (Figure 2).

HIV-1 IN concerted integration activities are closely linked to its multimerization state [68-70]; thus, we next analyzed the effects of these mutations on the reactions catalyzed in vitro by the retroviral enzyme. We first assessed the effect of these mutations on intrinsic 3' processing and strand transfer activities. The W131A, Q168L, K188Q and Y194F IN mutants retained near wild type 3' processing activity, while the Y194E mutant was impaired (Figure 3A lower panel and 3B lower panel). The W131A mutant also displayed wild type level of strand transfer activity. The mutations Q168L,
K188Q and Y194F partially decreased strand transfer activity. Again, mutant Y194E was more severely affected (Figure 3A upper panel and 3B upper panel). We next assessed the ability of these mutants to perform in vitro concerted integration under previously reported conditions [68]. Using a 296 bp DNA substrate containing the $21 \mathrm{nt}$ of both pre-processed HIV-1 U3 and U5 viral ends at each extremity, IN WT displayed a robust activity generating all the expected integration products including the half site integration product (HSI) and the full site integration product (FSI). IN W131A displayed a strong activity at 5 pmoles. Surprisingly, despite its monomeric elution profile in SEC (Figure 2), Q168L retained a significant catalytic activity. In sharp contrast, K188Q, Y194F and Y194E were almost incapable of concerted integration activities (Figure 3C).

In order to assess the impact of IN multimerization on LEDGF/p75 and TNPO3 binding, we first confirmed that our recombinant proteins were able to interact in a Ni-NTA pull-down assay. As expected, His-tagged wild type IN interacted with both full length GST-LEDGF/ p75 and GST-TNPO3, while the GST protein alone failed to be pulled down. IN also recovered the IBD of LEDGF/p75 that was previously identified in yeast 2hybrid screenings [14] (Additional file 1: Figure S1). In the absence of His-IN, none of the GST fusion proteins were recovered (data not shown). Next, we established a more quantitative assay to assess the binding properties of our mutants. In vitro interactions were studied by HTRF, a FRET-based assay using His-IN and either LEDGF/P75 or TNPO3 constructs tagged with GST. Recombinant proteins were incubated to form a complex in presence of anti-GST-EuCryptate/anti-His$\mathrm{XL665}$, and the transfer of energy between the two proteins yields a fluorescent signal only if they are in close proximity, i.e. if they are physically interacting. IN mutants were first characterized for their ability to bind LEDGF/p75. The His-IN::GST-LEDGF/p75 complex yielded a strong and reproducible signal reflecting the 


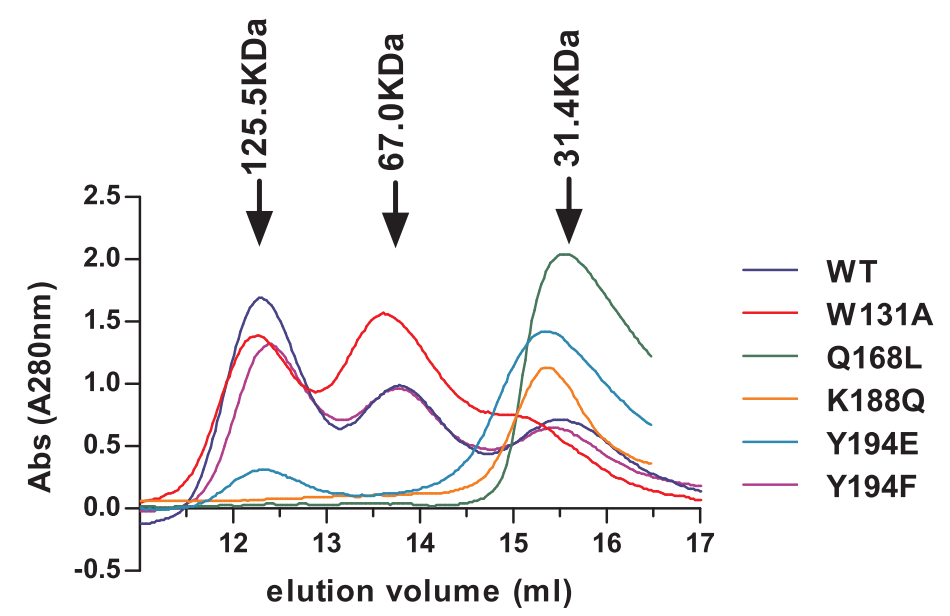

Figure 2 Oligomerization properties of WT and mutant INs. Size exclusion chromatography (SEC) elution profiles of IN proteins ( $2.5 \mu M$ ) versus elution volumes of protein standards (black arrows) are represented. The SEC profile of WT IN (dark blue) shows three peaks corresponding to tetramers, dimers and monomers, respectively. SEC profiles of IN mutants W131A, Q168L, K188Q, Y194E and Y194F are shown in red, green, orange, cyan and purple, respectively.

robustness of this assay. As previously reported, both IN W131A and IN Q168L displayed a weak interaction with LEDGF/p75 (9.3 and 16.3\% of IN WT interaction in our assay, respectively). Substitution of Lys 188 for a Gln also resulted to a $64.9 \%$ decrease of the binding to LEDGF/p75. While IN Y194F interacted with LEDGF/ p75 at wild type level, the substitution of Tyr for a negatively charged Glu or a neutral Ala moderately diminished IN binding to LEDGF/p75 by 26 and $27 \%$ respectively (Figure 4A).

The same assay was developed to quantify IN::TNPO3 interaction. Both IN mutants K188Q and Y194A interacted with TNPO3 as well as IN WT, while the substitution of Y194 to Phe or Glu resulted in a 14.4 and $23.5 \%$ decrease of TNPO3 binding. Surprisingly, the strongest decrease for TNPO3 binding was observed for both LEDGF/p75 interaction-defective integrase IN W131A and IN Q168L (49\% and 45\% of IN WT, respectively) (Figure $4 \mathrm{~B}$ ).

In order to determine the impact of these mutations on the viral replication in infected cells, they were introduced into the replicative Bru molecular clone; and viral stocks were produced. Among the IN mutants virus, only HIV-1 W131A displayed a severe reduction of viral particle release, yielding $16 \%$ of wild-type Cap24 release (Figure 5A). To assess the ability of IN mutant viruses to replicate, SupT1 cells were infected with equal amount of WT or mutant viruses, and viral replication was monitored by measuring p24 antigen in the supernatant of infected cells. Compared to the wild-type virus, HIV-1 W131A showed a 7 days delay in breakthrough whereas HIV-1 Q168L, HIV-1 K188Q, and
HIV-1 Y194E and HIV-1 Y194F mutants were replication-deficient (Figure 5B).

We analyzed the impact of IN mutations on early stages of HIV-1 replication using real-time quantitative PCR. Preliminary observations in HeLa cells indicated that some of our IN mutant viruses displayed strong cDNA synthesis defects when pseudotyped with the vesicular stomatitis virus glycoprotein (VSVg) (Additional file 2: Figure S2). Interestingly, these defects could be compensated when viruses entered cells by fusion using HIV-1 gp120 envelope suggesting that IN mutations could affect pre-integration steps specific to the VSVg-mediated endocytic pathway (Figure 6A and Additional file 2: Figure S2). Thus, utilizing real-time quantitative PCR, we first measured late reverse transcribed (LRT) viral cDNA products, 2-LTR circles and integrated proviral DNA in SupT1 cells infected with IN mutant viruses encoding HIV-1 env. In this experiment, virus replication was restricted to a single round infection by addition of Saquinavir, a protease inhibitor. At 7 h post infection, HIV-1 WT, HIV-1 Q168L, HIV-1 K188Q, HIV-1 Y194E and HIV-1 Y194F viruses synthesized similar amount of LRT viral cDNA products, whereas HIV-1 W131A displayed a 2.7-fold defect (Figure 6A). Detection of 2-LTR circle forms of viral HIV-1 cDNA is indicative of nuclear import of the viral genome. At 24h p.i., HIV-1 Q168L, HIV-1 K188Q, HIV-1 Y194E and HIV-1 Y194F mutant viruses converted equal or slightly higher amounts of 2-LTR circles (1.3fold, 1.0-fold, 1,2-fold and 1.6-fold, respectively) compared to the wild type virus whereas HIV-1 W131A yielded an approximate 4-fold reduction (Figure 6B). 

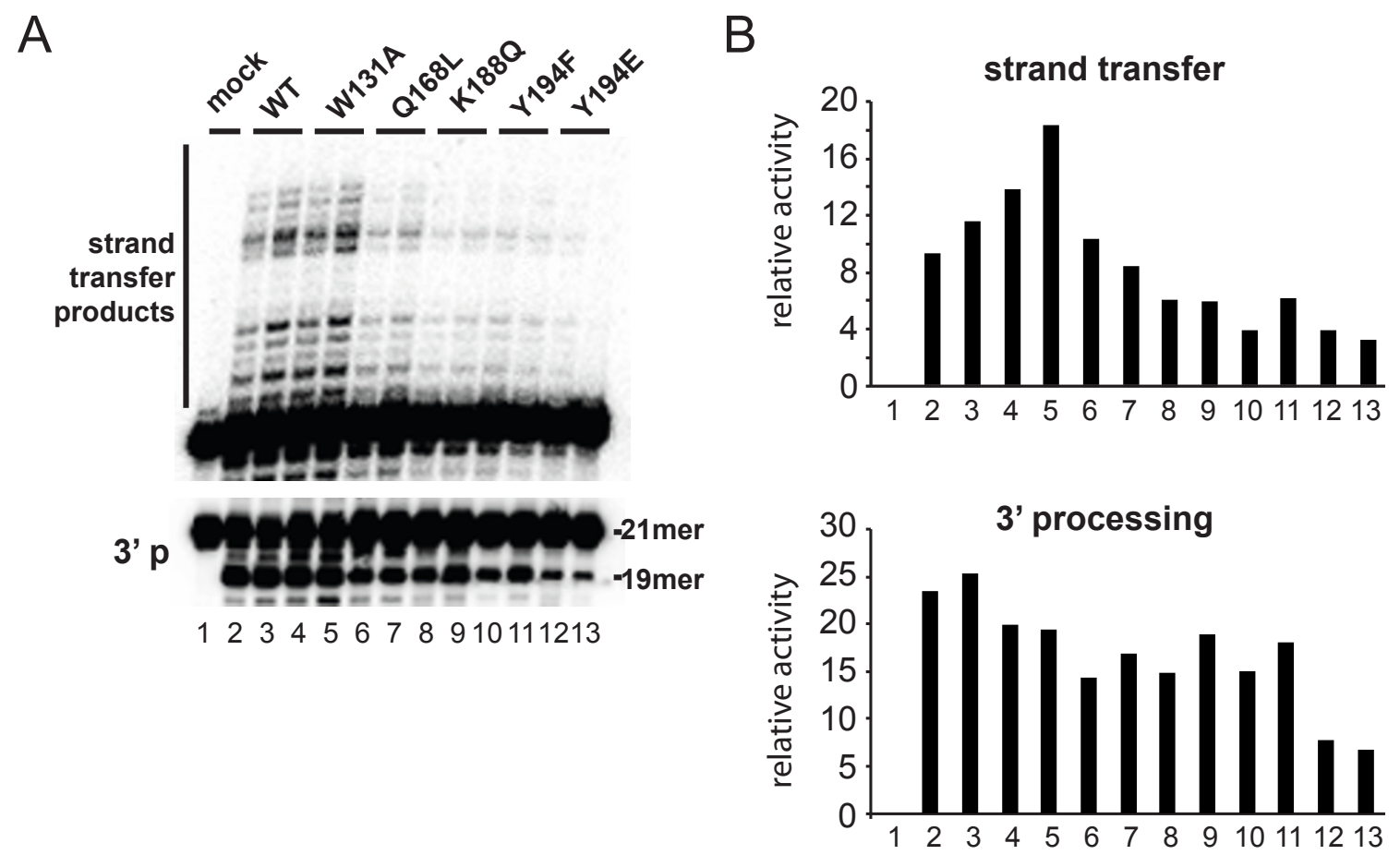

C

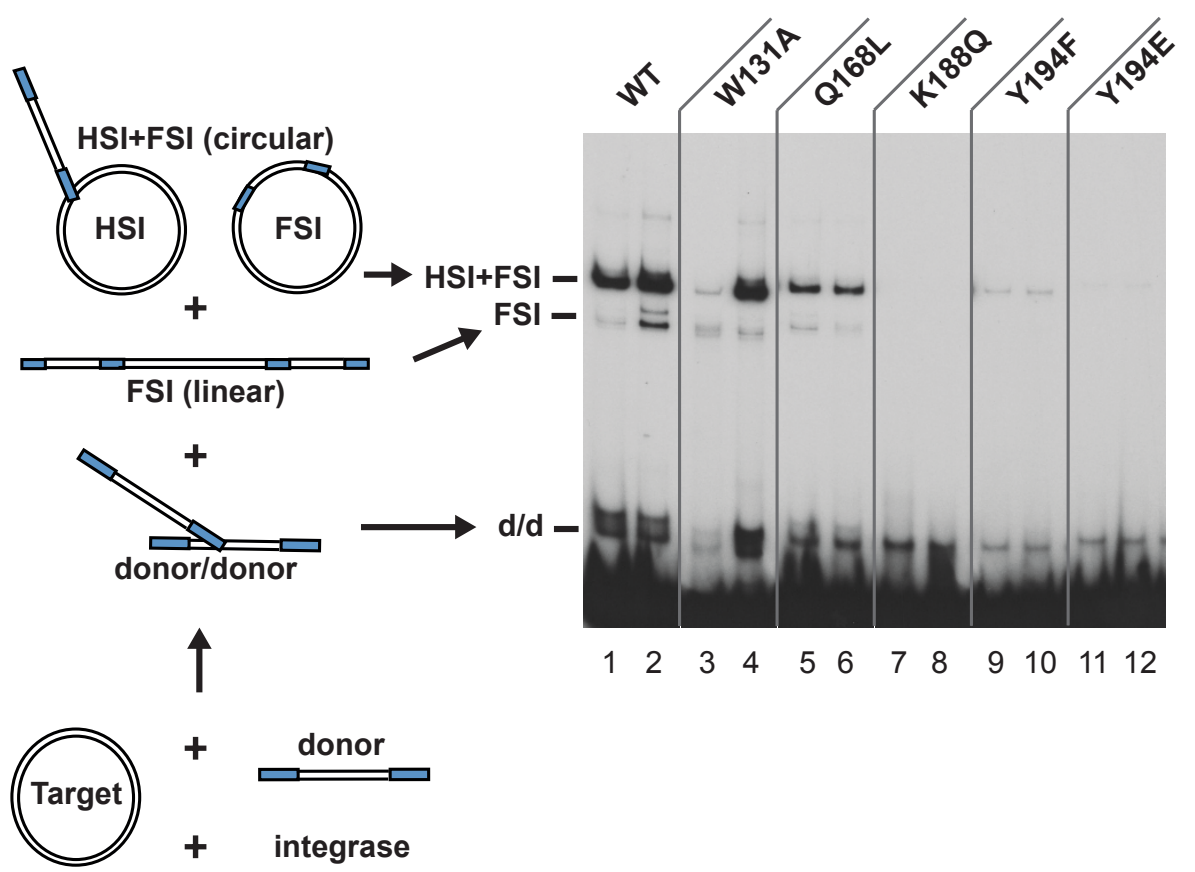

Figure 3 Enzymatic activities of WT and mutant INs. (A) 3' processing and strand transfer activities of IN mutants. Using an oligonucleotidebased assay, activities of recombinant INs were tested at two different concentrations: $100 \mathrm{nM}$ (lanes 2, 4, 8, 10, 12); or 120 nM (lanes 3, 5, 7, 9, 11, 13). Reaction products were separated in a denaturing urea gel and visualized with a STORM Phosphorlmager (Molecular Dynamics). (B) Quantification of 3'-processing and strand transfer activities of IN mutants. Gels from figure 3A were quantified with Image QuantTM 4.1 software. (C) Concerted integration assay was performed using IN (2 pmoles, lanes 1, 3, 5, 7, 9, 11 and 5 pmoles, lanes 2, 4, 6, 8, 10, 12), 150 ng of naked acceptor DNA (3000 bp) and $15 \mathrm{ng}$ of ${ }^{32} \mathrm{P}$ 5'-labelled donor pre-processed DNA (296 bp). The reaction products were loaded on $1 \%$ agarose. The positions of the different products obtained after half-site integration (HSI), full-site integration (FSI) and donor/donor integration (d/d) are reported. 

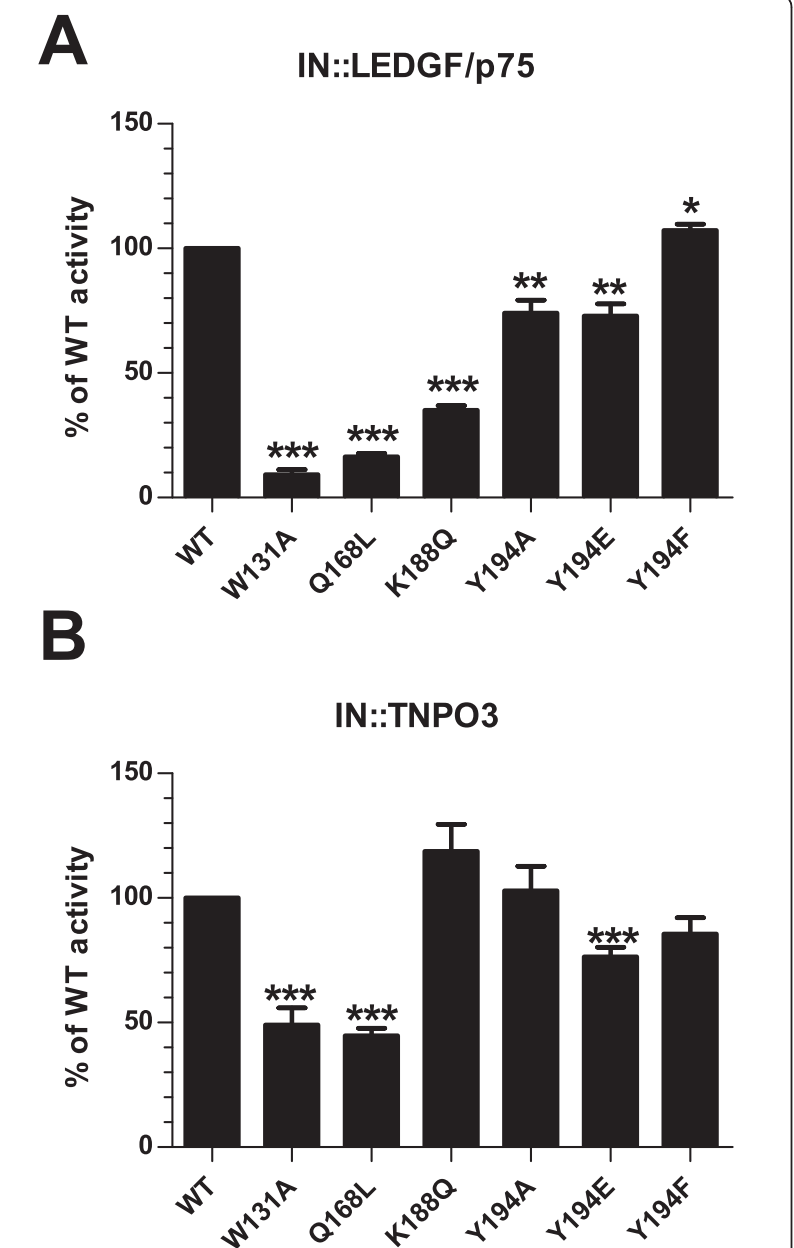

Figure 4 In vitro interaction assay of IN mutants with LEDGF/ p75 and TNPO3. Interaction between INs and LEDGF/p75 (A) or TNPO3 (B) was measured by HTRF. GST-LEDGF/p75 (5 nM) or GSTTNPO3 (5 nM) and His-IN WT or indicated IN mutants ( $80 \mathrm{nM})$ were incubated with anti-GST-Europium Cryptate and anti-His-XL antibodies. HTRF signal was read at $2 \mathrm{~h}$ post incubation in a Pherastar (BMG) at 665 and $620 \mathrm{~nm}$ after excitation at $337 \mathrm{~nm}$. HTRF signals of indicated IN mutants were expressed as a percent IN WT $\Delta F$. Results are an average of three (IN::LEDGF/p75) or four (IN:: TNPO3) experiments performed in duplicate. Statistical significance values were calculated using a student two-sided $t$ test. ${ }^{* * *}, P<$ $0.0001 ;{ }^{* *}, P<0.001 ;{ }^{*}, P<0.01$.

When normalized to the quantity of LRT viral cDNA products , HIV-1 W131A displayed about $63 \%$ of the wild-type 2-LTR circles level, whereas HIV-1 Q168L, HIV-1 K188Q, HIV-1 Y194E and HIV-1 Y194F displayed about $145 \%, 90 \%, 140 \%$ and $146 \%$ of the HIV-1 WT, respectively (Figure 6C). Finally, levels of integrated proviruses at $48 \mathrm{~h}$ p.i. were severely reduced for all the mutants (12 to $24 \%$ of that of the wild type), indicating that these mutations primarily impact the integration step (Figure 6D).
IN mutations affecting both nuclear import and integration could result in opposite effects on the accumulation of 2-LTR circles in the nucleus. Because IN mutants W131A and Q168L are impaired for interaction with both TNPO3 and LEDGF/p75, we decided to assess more precisely the impact of these mutations on nuclear import in the absence of LEDGF/p75. Using LEDGF/ p75-depleted SupT1 cells [71], we quantified 2-LTR circles levels upon infection with our mutant viruses. LRT viral cDNA products and 2-LTR circles were quantified at $7 \mathrm{~h}$ and $24 \mathrm{~h}$ p.i., respectively. For this experiment, LRT viral cDNA products were quantified using primers and a Taqman probe within the env region [72]. When compared to the WT virus, HIV-1 W131A and HIV-1 Q168L displayed about 50.7\% and 36.9\% decrease in LRT viral cDNA products, respectively. In contrast, HIV-1 K188Q synthesized amounts of reverse transcribed viral cDNA products similar to wild type level (111.6\%) (Figure 7A). At 24 h p.i., HIV-1 W131A and HIV-1 Q168L displayed 31.3\% and $72.4 \%$ of wild type levels of 2-LTR circles, respectively, whereas HIV-1 K188Q displayed a 1.6-fold increase (Figure 7B). When normalized to the quantity of LRT viral cDNA products, HIV-1 W131A, HIV-1 Q168L and HIV-1 K188Q converted $65.5 \%, 114.9 \%$ and $146.0 \%$ of their $L R T$ viral cDNA products in to 2-LTR circles, respectively (Figure 7C). Together, these data suggest that IN mutations reducing TNPO3 binding have a rather limited effect (W131A) or no effect (Q168L) on nuclear import of the PIC.

\section{Discussion}

Site-direct mutagenesis experiments previously identified LEDGF/p75-binding deficient IN mutants $[14,15,17]$. Among the residues analyzed in this study, W131 is the only one that makes a direct contact with LEDGF/p75 IBD. W131 forms hydrophobic contacts with LEDGF/ p75 residues F406 and V408. The side chain of the surface exposed W131 residue was shown to rotate upon LEDGF/p75 binding [24], and mutation of this residue significantly impaired LEDGF/p75 interaction $[17,73]$. The elution profile of W131A resembled the one of IN WT consisting of a mixture of mono-, di- and tetramers with a predominance of dimeric forms (Figure 2). Consistent with this observation, IN W131A reached near WT concerted integration activity at its highest concentration (Figure 3B).

Our structure-function analysis of IN mutants identified residues important for the oligomerization of IN. Mutations Q168L, K188Q and Y194E that destabilized IN multimers also affected LEDGF/p75 binding in our HTRF assay. Whereas the Q168 residue is not directly binding LEDGF/p75 IBD, it forms a hydrogen bound with W132 that is important for the IN dimer interface 


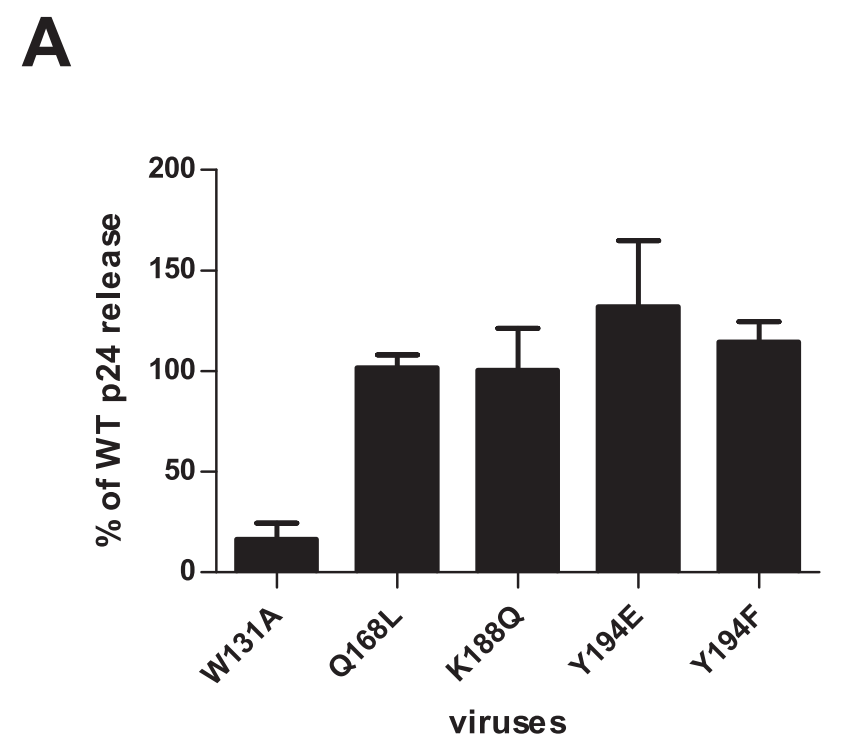

B

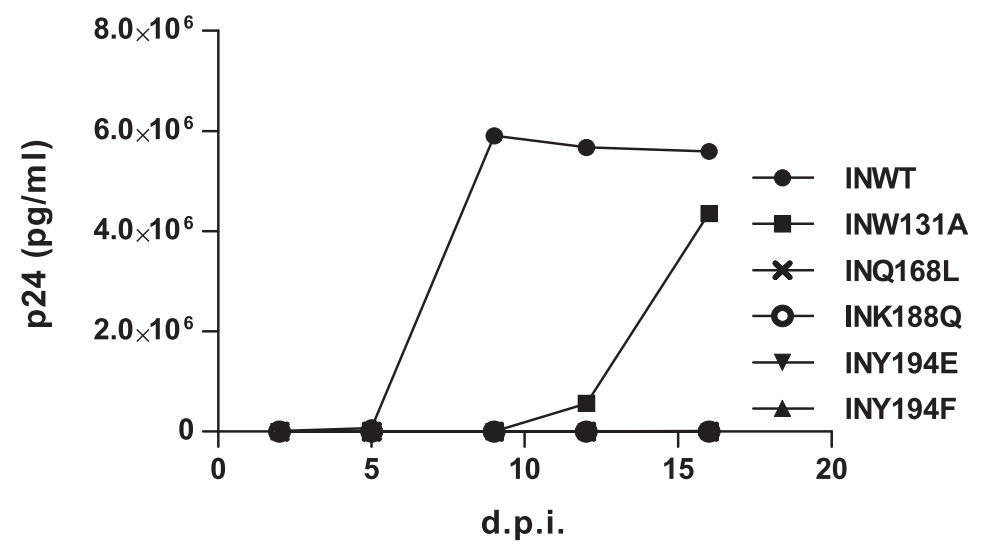

Figure 5 Analysis of viral production and replication. (A) 293T cells were transfected with the WT or mutant pBru molecular clones. Viral release was monitored by quantification of CAp24 antigen in the supernatant of the producer cells $48 \mathrm{~h}$ after transfection. Results are represented as a percentage of WT CAp24 release. Error bars represent standard deviations of duplicate transfections. (B) SupT1 cells were infected with equal amounts of viruses. Viral replication was followed at indicated d.p.i. by measuring CAp24 antigen in the supernatant of infected cells.

and mutations altering Q168 impaired LEDGF/p75 binding (Figure 4A). The Q168L mutant behaved solely as a monomer, confirming that alteration of the conformation of the CCD $\alpha 4 / \alpha 5$ connector reduces IN affinity for LEDGF/p75 (Figure 4A). The result of this conformational alteration provides an explanation for the replication defect previously described for HIV-1 Q168L $([14,17,73]$ and Figure 5B). The residues K188 and Y194 are within the constrained loop contributing to the IN tetrameric interface $[26,27]$. Consistent with previous results, we found that IN K188Q mutant was predominantly monomeric (Figure 2) and showed almost 3-fold decrease for LEDGF/p75 interaction (Figure 4A). Mutation Y194E was also compromised for tetramer formation, although to a lesser extent, as tetramers forms were still present. Accordingly, this mutation resulted in a $25 \%$ decreased affinity for LEDGF/p75. In sharp contrast, Y194F displayed WT SEC profile and retained high affinity for LEDGF/p75.

On the other hand, this mutagenesis study could not establish a correlation between the formation of IN tetramers and TNPO3 binding. Indeed, W131 A and Q168L displayed the strongest decreases in TNPO3 binding while showing opposite oligomerization profiles. 


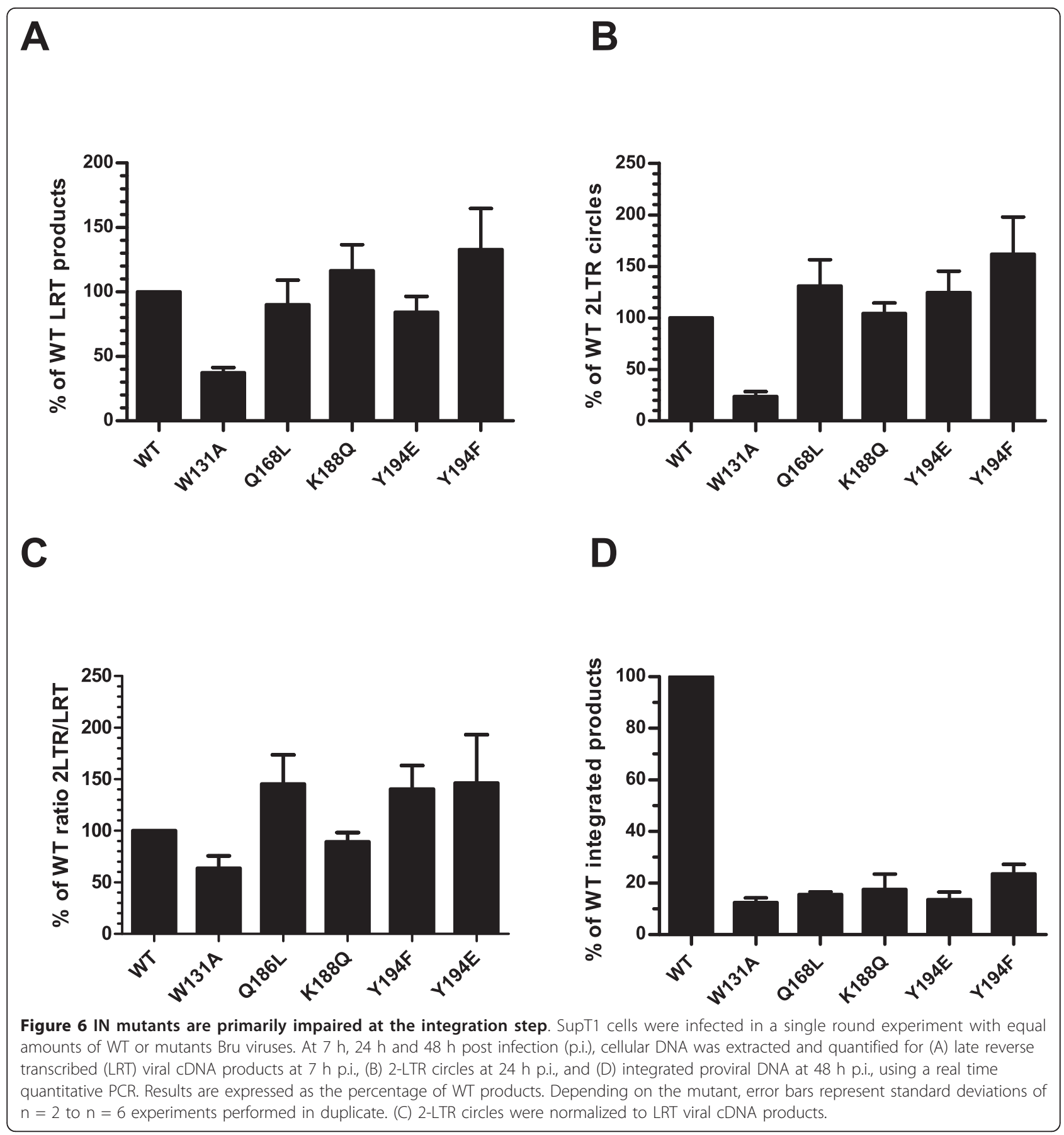

Furthermore, the ability of monomeric IN to interact with TNPO3 was further confirmed with the mutant K188Q. These results suggest that TNPO3 could bind to a surface of monomeric IN that remains exposed after tetramerization. Despite its SEC monomeric profile, the Q168L mutant retains some catalytic activity in vitro. However this mutation must alter the overall conformation of the protein and its ability to interact with cellular cofactors. On the contrary, the W131A mutant displayed in vitro catalytic activities as well as multimerization profile similar to the wild type IN, indicating that this mutation has limited impact on the conformation of the protein. Results from our HTRF assay confirmed previous studies showing that both IN W131A and IN W131D were defective for LEDGF/p75 binding in His-IN pull down assays [15,17].

We observed that the oligomerization profiles of IN mutants in solution could not completely predict their 

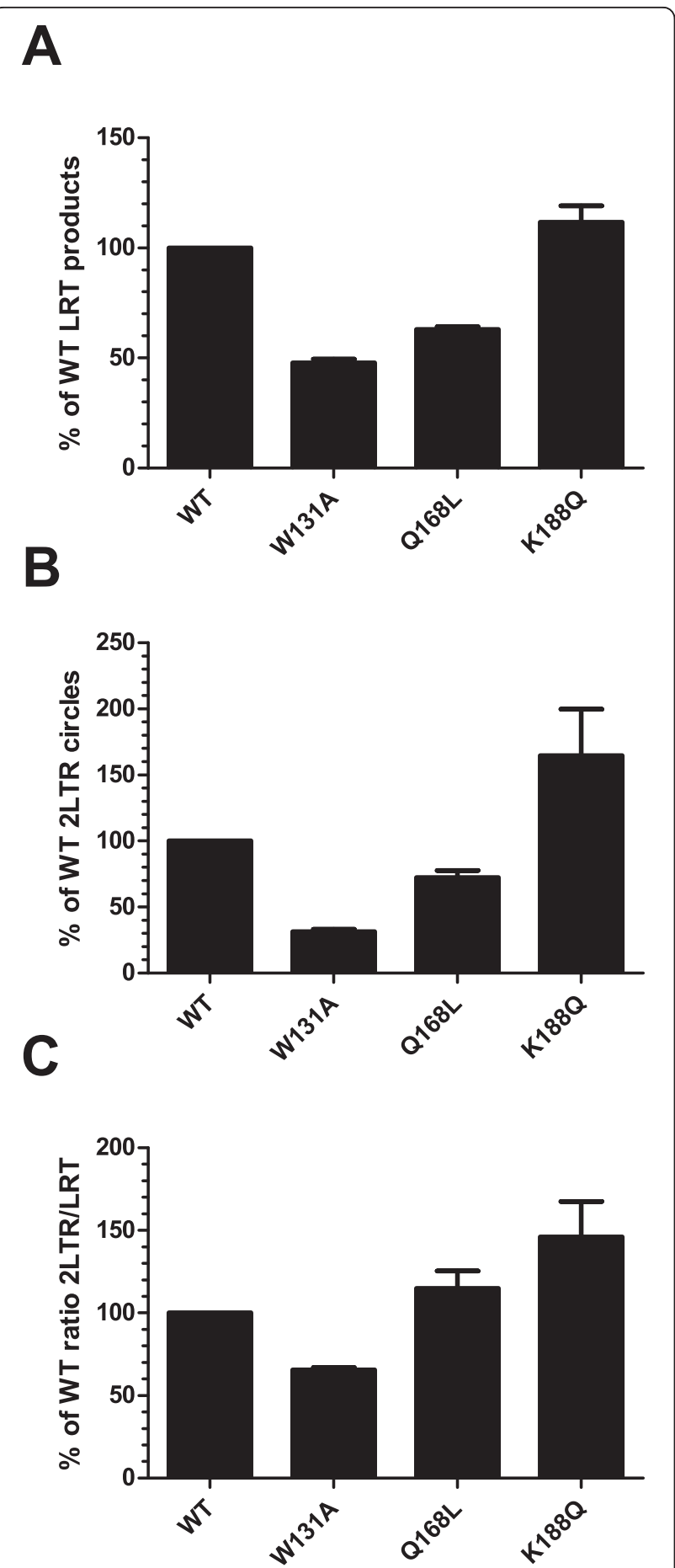

Figure 7 IN mutants are not significantly affected at the nuclear import step. SupT1 TL34 cells depleted for LEDGF/p75 were infected in a single round experiment with equal amounts of WT or mutants Bru viruses. Cellular DNA was extracted and quantified for (A) late reverse transcribed (LRT) viral cDNA products at $7 \mathrm{~h}$ p.i., (B) 2-LTR circles at $24 \mathrm{~h}$ p.i., using a real time quantitative PCR. (C) 2-LTR circles were normalized to LRT viral CDNA products. Error bars represent standard deviations of $n=2$ experiments performed in duplicate. Results are expressed as the percentage of WT products. capacities to perform concerted strand transfer reaction. This is exemplified by the ability of the mutant Q168L to retain partial concerted integration activity (Figure $3 \mathrm{~B})$, suggesting that the monomeric IN Q168L could oligomerize in presence of DNA. We also observed that mutations of the residue Y194 strongly affected the enzymatic activity of the protein independently of their abilities to tetramerize probably by affecting directly the catalytic property of the protein (Figure 3A).

Our interaction assays indicate that IN mutants W131A and Q168L are the most deficient for TNPO3 interaction. The primarily replication defect of HIV-1 W131A takes place during reverse transcription indicating that this mutation somehow impacts the RTC conformation. Subsequently, the slight reduction in 2-LTR circles could be an indirect consequence of the reverse transcription defect. On the other hand, the HIV-1 Q168L virus displayed modest increase of 2-LTR circles level and viral replication appears to be mainly impaired at the integration step (Figures 6 and 7). Mutations of IN affecting simultaneously nuclear import and integration would have opposite effects on the accumulation of 2-LTR circles in the nucleus, resulting in a null effect. To uncoupled the phenotype of these mutant viruses on nuclear entry from the phenotype due to the defective interaction between IN and LEDGF/p75, we quantified 2-LTR circle levels in LEDGF/p75-depleted cells [71]. Similar to the results obtained in SupT1 cells, we observed a $30 \%$ decrease in the formation of 2-LTR circles for HIV-1 W131A, whereas HIV-1 Q168L accumulated near wild type amounts (Figure 7C). Therefore, the study of these two IN mutants showed that no direct correlation could be found between a defect in TNPO3 binding and the formation of 2-LTR circles. Taken together, these results suggest that the interaction between IN and TNPO3 is not directly involved at the nuclear import step, but could rather take place at a later stage in the nucleus. As quantification of 2-LTR circles is only an indirect measurement of nuclear import, these results should be confirmed using more direct methods $[74,75]$. Nevertheless, these results corroborate mounting evidence against a direct role of IN in controlling the shuttling of the PIC between the cytoplasm and the nucleus in dividing or non-dividing cells $[76,77]$.

Furthermore, CA was found to be the dominant viral determinant for HIV-1 infection of non-dividing cells. The kinetic of dissociation of CA from the viral core appears to be a critical step that could control subsequent interactions with cellular karyopherins [40,41]. Recently, HIV-1 CA mutant N74D was shown to escape replication restriction observed upon TNPO3 depletion [66]. This result reinforces previous observations for a role of CA as the main viral determinant for TNPO3 
dependency during HIV-1 infection [64-66]. However, whereas the importance of $\mathrm{CA}$ as the main determinant of TNPO3-dependency for HIV-1 replication is well supported by experimental evidence [64-66], proof of a direct interaction between CA and TNPO3 is still missing. Using TNPO3 as bait in a rebound yeast two-hybrid screening against a prey library of random HIV-1 fragments, we identified IN, but not CA, as the binding partner of TNPO3 $[62,63]$. However, it would be important to determine if multimerization of $\mathrm{CA}$ is required for TNPO3 binding. Recently, TNPO3 has been shown to pull-down CA as well as tRNA from purified virions in a RanGTP-manner, and a model has been proposed in which TNPO3 could displace CA and tRNA that remain associated to nuclear PICs in order to facilitate integration [78]. Whether this mechanism involves a direct interaction between TNPO3 and CA in the nucleus remains to be explored.

Beside the role of CA, a direct interaction between IN and TNPO3 could take place after entry of the PIC in the nucleus. Therefore, beside its role in nuclear import, TNPO3 could also be involved in nuclear events of HIV-1 replication. This model is supported by recent findings showing that depletion of TNPO3 affected a post-import step of HIV-1 replication [78], and it was recently shown that by regulating nuclear import of the PIC in a CA-dependent manner, both NUP358/RanBP2 and TNPO3 control the selection of integration sites in the chromosomes of the host cell [79]. This latter study proposed an interesting model in which nuclear translocation through the pore would result in the specific targeting of PICs in gene dense regions of the genome, a step that could required a direct interaction between IN and TNPO3.

An intriguing question remains regarding the pleiotropic effects of the mutation W131A on HIV-1 replication. Similar to our observations with HIV-1 W131A, a defect of viral cDNA synthesis was also described for the VSVgpseudotyped HIV-1 W131A and HIV-1 W131D viruses $[15,17]$. IN mutants have been reported to perturb the reverse transcription step, possibly by altering the overall conformation of the RTC [80]. A direct interaction between IN and RT was reported and could account for these effects [81]. In addition, HIV-1 viruses carrying IN deletion or the C130S substitution were recently described to decrease CypA-CA interaction leading to the destabilization of the viral core [82]. Future experiments would be required to assess the kinetic of CA uncoating of IN mutated viruses depending of their mechanism of entry (i.e. fusion vs. endocytosis).

\section{Conclusion}

Interactions between IN and host cellular factors control different stages of HIV replication. TNPO3 was recently described as a HIV-1 dependency factor able to bind HIV-1 IN, and RNAi studies indicated that TNPO3 participates in the import of the PIC into the nucleus $[53,55,62]$. Our site-directed mutagenesis analysis aimed at exploring the contribution of the interaction between IN and TNPO3 to the early stages of the viral lifecycle. The present study indicates that IN mutants W131A and Q168L previously shown to be defective for LEDGF/p75 were also impaired for TNPO3 binding, albeit to a lesser extent. However, none of these mutations significantly reduced the level of the 2-LTR circles, arguing against a role of IN-TNPO3 interaction in nuclear import.

\section{Methods}

\section{Cells, viruses and infections}

HeLa and 293T cells were grown in Dulbecco's modified Eagle's medium supplemented with $10 \%$ of fetal calf serum and antibiotics (100 units/ml penicillin G, 100 $\mathrm{mg} / \mathrm{ml}$ streptomycin; GIBCO, Invitrogen). SupT1 and LEDGF-depleted SupT1 TL34 cells [71] were grown in RPMI 1640 supplemented with 10\% of fetal calf serum and antibiotics (100 units/ml penicillin G, $100 \mathrm{mg} / \mathrm{ml}$ streptomycin; GIBCO, Invitrogen).

\section{Viral production}

Bru WT or IN mutant virus stocks were generated by transfecting 293T cells with pBru-derived molecular clones using PEI (Polyethylenimine, Polysciences). Cells were washed $16 \mathrm{~h}$ after transfection, and supernatants collected $24 \mathrm{~h}$ thereafter were filtered through $0.45 \mu \mathrm{m}$ filters and aliquoted. Viral stocks were quantified by measuring the CAp24 antigen using the Innotest HIV Antigen mAb kit, accordingly to manufacturer instructions (Innogenetics).

\section{Viral replication}

SupT1 or Sup T1 TL34 cells were infected with viral doses corresponding to 100 ng of HIV-1 CAp24 antigen per $2.10^{6}$ cells, viral replication of each mutant viruses compare to the WT was followed by monitoring the HIV-1 CAp24 in the producer cells supernatants as described above.

\section{Plasmids and mutagenesis His $_{6}$-tagged integrases}

Mutated recombinant IN Q168L, IN W131A, IN K188Q, IN Y194E, IN Y194F were obtained by sitedirected mutagenesis of the pINSD.His plasmid $[83,84]$. IN mutations were introduced into the pBru molecular clone by site-directed mutagenesis.

\section{Expression and purification of recombinant proteins}

GST-LEDGF/p75 encoding sequence was introduced in the pGGWA plasmid using the gateway system (Invitrogen, Stratagene). Recombinant GST proteins were 
produced in Escherichia coli BL21. E. coli transformed with GST-TNPO3 or GST-LEDGF/p75 expression constructs were grown in $\mathrm{LB}$ medium at $37^{\circ} \mathrm{C}$ to an $\mathrm{A}_{600}$ of 0.9-1.0 prior to induction with $1 \mathrm{mM}$ isopropyl-thio-Dgalactopyranoside (IPTG) for $4 \mathrm{~h}$ at $37^{\circ} \mathrm{C}$. Bacteria were harvested by centrifugation and lysed by sonication in GST lysis buffer A (1 M NaCl, $40 \mathrm{mM}$ Hepes $\mathrm{pH}$ 7.0, 5 $\mathrm{mM} \mathrm{MgCl} 2$, $5 \%$ glycerol, $7 \mathrm{mM}$ CHAPS, $2 \mathrm{mM} \beta$-mercaptoethanol) supplemented with protease inhibitor mixture (Roche) and $1 \mathrm{mM}$ phenylmethylsulfonyl fluoride. Lysates were first clarified by centrifugation at $18000 \times g$ for $50 \mathrm{~min}$ at $4^{\circ} \mathrm{C}$ and then incubated with $500 \mu \mathrm{l}$ glutathione-Sepharose (settled beads volume, GE Healthcare) for $1 \mathrm{~h}$ at $4^{\circ} \mathrm{C}$. Sepharose beads were washed twice with $20 \mathrm{ml}$ of cold-ice GST lysis buffer, and recombinant proteins were eluted in $500 \mu \mathrm{l}$ of GSTlysis buffer supplemented with $20 \mathrm{mM}$ reduced gluthatione $\mathrm{pH}$ 7.0. His $_{6}$-tagged IN WT and IN mutant proteins were purified by nickel affinity as previously described [85]. N-terminal $\mathrm{His}_{6}$-tag was removed by digestion with $200 \mathrm{U} / \mathrm{mg}$ thrombin (Sigma) $\mathrm{O} / \mathrm{N}$ at $4{ }^{\circ} \mathrm{C}$ and injected into a $5 \mathrm{ml}$ HiTrap heparin column attached to an AKTA purifier system (GE Healthcare). Bound protein was eluted with a linear gradient of 0.25 to $1.0 \mathrm{M} \mathrm{NaCl}, 7 \mathrm{mM}$ CHAPS, $50 \mathrm{mM}$ Tris $\mathrm{HCl} \mathrm{pH}$ 7.4.

\section{$\mathrm{His}_{6}$-tag pull-down assay}

Binding of IN to TNPO3, LEDGF/p75 or LEDGF/p75IBD was assayed in pull-down buffer (PB): $150 \mathrm{mM}$ $\mathrm{NaCl}, 25 \mathrm{mM}$ Imidazole, $2 \mathrm{mM} \mathrm{MgCl}_{2}, 0,1 \% \mathrm{NP} 40,50$ $\mathrm{mM}$ Tris $\mathrm{HCl} \mathrm{pH}$ 7.4. Two $\mu \mathrm{g}$ of recombinant $\mathrm{His}_{6}$ tagged HIV-1 IN were incubated with $2 \mu \mathrm{g}$ of GST, GST-TNPO3 FL, GST-LEDGF/p75 FL or GST-LEDGF/ p75 IBD in $200 \mu \mathrm{l}$ of PB. Following a $2 \mathrm{~h}$ incubation at $4{ }^{\circ} \mathrm{C}$, the mixtures were centrifuged briefly at full speed to remove aggregated proteins. Samples were supplemented with $20 \mu \mathrm{l}$ (settled beads volume) of $\mathrm{Ni}$-charged resin (Bio-Rad) and with $10 \mu \mathrm{g}$ of bovine serum albumin (BSA). The mixtures were incubated for an additional 2 $\mathrm{h}$ at $4^{\circ} \mathrm{C}$. Beads were recovered by centrifugation and washed three times with $1 \mathrm{ml}$ of ice-cold PB. Beads were boiled in $20 \mu \mathrm{l} 2 \times$ Laemmli (Sigma). Eluted proteins were separated by SDS-PAGE and detected by staining with Page blue protein staining solution (Fermentas).

\section{Size exclusion chromatography}

Experiments were performed with $2.5 \mu \mathrm{M}$ of untagged IN on a Superdex $20010 / 300$ GL column attached to an AKTA purifier system (GE Healthcare) at flow rate $0.5 \mathrm{ml} / \mathrm{min}$ in buffer containing $50 \mathrm{mM}$ HEPES $(\mathrm{pH}$ $7.4), 750 \mathrm{mM} \mathrm{NaCl}$, and $10 \%$ glycerol. If it was necessary, proteins were diluted in this buffer before injection. Proteins were detected by absorbance at $280 \mathrm{~nm}$. The column was calibrated with the following proteins: thyroglobuline $(669 \mathrm{kDa})$, apoferritine $(443 \mathrm{kDa}), \beta$-amylase $(200 \mathrm{kDa}), \mathrm{ADH}(150 \mathrm{kDa})$, albumin $(66 \mathrm{kDa})$ and carbonic anhydrase (29 kDa) (MW-GF-100 kit, Sigma).

\section{HTRF $^{\circledR}$ assay (Homogeneous Time Resolved Fluorescence)} Assays were carried out in a black 384-halfwell microplate (Greiner) using the following Interaction Buffer (IB): $25 \mathrm{mM}$ Hepes pH 7.3, $150 \mathrm{mM} \mathrm{NaCl}, 2 \mathrm{mM}$ $\mathrm{MgCl}_{2}, 0,1 \%$ BSA, 1 mM DTT. Recombinant proteins were diluted in IB and used at a final concentration of $80 \mathrm{nM}$ for His-IN and $5 \mathrm{nM}$ for GST-TNPO3 or GSTLEDGF/p75. Anti-GST Europium Cryptate and antiHis-XL from CisBio International were reconstituted as recommended. Antibodies were firstly diluted (1/200) in IB supplemented with $0.8 \mathrm{mM}$ Potassium Fluoride, 1 $\mathrm{mM}$ DTT and used at a final dilution 1/400. After addition of the interacting proteins and both antibodies in a final reaction volume $20 \mu \mathrm{l}$, the microplate was read at different times in a PHERAstar (BMG) at 665 and 620 $\mathrm{nm}$ after excitation at $337 \mathrm{~nm}$. The specific HTRF signal was expressed as a percentage of $\Delta \mathrm{F}$ and calculated as follows: $\Delta \mathrm{F}(\%)=\{[(665 / 620)$ sample- $(665 / 620)$ blank $] /$ $(665 / 620)$ blank $\}^{*} 100$.

\section{In vitro integration assays and concerted integration}

$3^{\prime}$ processing and strand transfer activity assays were carried out at $37^{\circ} \mathrm{C}$, in a buffer containing $20 \mathrm{mM}$ HEPES (pH 7.2), $1 \mathrm{mM}$ DTT, $7.5 \mathrm{mM} \mathrm{MnCl}_{2}$ in the presence of $12.5 \mathrm{nM}$ DNA substrate and $60 \mathrm{nM}$ or 120 $\mathrm{nM}$ of IN as previously described [86]. Products were separated by electrophoresis in denaturing $18 \%$ acrylamide/urea gels. Gels were analyzed with a Molecular Dynamics STORM phosphoimager and quantified with Image Quant ${ }^{\mathrm{TM}} 4.1$ software. Concerted integration was measured as previously described [68]. Briefly purified HIV-1 IN ( 2 and 5 pmoles) was pre-incubated with both the 5'-end-labeled donor DNA (15 ng) containing the pre-processed U3 and U5 LTR sequences and the target DNA plasmid $\mathrm{pBSK}^{+}(150 \mathrm{ng})$ at $0^{\circ} \mathrm{C}$ for $20 \mathrm{~min}$ in a total volume of $5 \mu \mathrm{l}$. Then the reaction mixture $(20$ mM HEPES, pH 7.5; $10 \mathrm{mM}$ DTT; $10 \mathrm{mM} \mathrm{MgCl}_{2} ; 15 \%$ DMSO; $8 \%$ PEG, $30 \mathrm{mM} \mathrm{NaCl}$ ) was added and the reaction proceeded for $120 \mathrm{~min}$ at $37^{\circ} \mathrm{C}$ in a total volume of $10 \mu \mathrm{L}$. Incubation was stopped by adding a phenol/isoamyl alcohol/chloroform mix $(24 / 1 / 25 \mathrm{v} / \mathrm{v} / \mathrm{v})$. The aqueous phase was loaded on a vertical $1 \%$ agarose gel in the presence of $1 \%$ bromophenol blue and $1 \mathrm{mM}$ EDTA. After separation of the products, the gel was treated with 5\% TCA for 20 min, dried and autoradiographed. All IN activities were quantified by scanning of the bands (half-site plus full-site integration products) after gel electrophoresis and autoradiography using the Image J software. 
Quantification of HIV-1 late reverse transcribed (LRT) viral CDNA products, two-LTR circles and integrated DNA

Prior to infection, viral stocks were treated $1 \mathrm{~h}$ at $37^{\circ} \mathrm{C}$ with $100 \mathrm{U}$ per ml of DNAseI (Roche). SupT1 or SupT1 TL34 cells $\left(6.10^{6}\right)$ were infected with viral doses corresponding to $1 \mu \mathrm{g}$ of HIV-1 CAp24 antigen per $2.10^{6}$ cells in 6-wells plates with Bru WT or IN mutant viruses. At $2 \mathrm{~h}$ post-infection (p.i.), cells were washed twice in phosphate buffered saline (PBS) $1 \mathrm{X}$, and $2.10^{6}$ cells were plated in 12 wells plates in presence of Saquinavir $(0.5 \mu \mathrm{M})$ to limit viral infection to a single round. At $7 \mathrm{~h}, 24 \mathrm{~h}$ and $48 \mathrm{~h}$ p.i. cells were harvested, washed twice in PBS $1 \mathrm{X}$ and DNA was extracted using the QIAamp Blood DNA Minikit (Qiagen). Quantifications of viral DNA were performed by real-time PCR using the LightCycler 480 system (Roche). The PCR reactions contained LightCycler480 Probes Master mix including the FastStart Taq DNA Polymerase, dNTPs and $6.4 \mathrm{mM}$ $\mathrm{MgCl}_{2}$. Primers, probes, QPCR run conditions were described previously [87]. The copy number of HIV-1 LRT viral cDNA products and 2-LTR circles were determined using standard curves obtained by amplification of cloned DNA containing the matched sequences. The copy number of integrated HIV-1 DNA was determined in reference to a standard curve generated by concomitant two-stage PCR amplification of a serial dilution of the standard HeLa R7 Neo cell DNA [88]. The copy number of each viral form was normalized with the number of cells obtained by the quantification by PCR of the $\beta$-globin gene according to the manufacturer instructions (Roche). When SupT1 TL34 cells were used, LRT viral cDNA products were quantified using a Taqman probe and primers within the env region as described previously [72].

\section{Additional material}

Additional file 1: Figure S1. HIV-1 IN interacts with LEDGF/p75 and TNPO3 in vitro. Recombinant His-IN was incubated with GST, GSTLEDGF/p75-IBD, GST-LEDGF/p75 and GST-TNPO3 and assayed in a Ni-NTA pull-down experiment. The pull-downed proteins were separated in SDSPAGE gels and detected by staining with Coomassie Blue G250. The positions of protein MWM are indicated.

Additional file 2: Figure S2. VSVg pseudotyped HIV-1 IN mutant viruses are affected at the reverse transcription step. HeLa cells $\left(2.10^{5}\right)$ were infected with viral doses corresponding to $1 \mu \mathrm{g}$ of HIV-1 CAp24 antigen cells in 6-wells plates with VSVg pseudotyped Bru WT or IN mutant viruses. At $7 \mathrm{~h}$ p.i., cells were harvested, washed twice in PBS $1 \mathrm{X}$ and DNA was extracted using the QIAamp Blood DNA Minikit (Qiagen). Quantifications of LRT viral CDNA products were performed by real-time PCR using the LightCycler 480 system (Roche).

\section{Acknowledgements}

This work was supported by the Agence Nationale de la Recherche sur le Sida et les Hépatites (ANRS) and SIDACTION to SE and the Agence Nationale de la Recherche (ANR) (ANR-06-RIB-021-02 and ANR-09-BIOT-006-02) to SE,
RB and MR. AC was supported by graduate student fellowships from the Minstère de l'Enseignement Supérieur et de la Recherche and the Fondation pour la Recherche Médicale.

We are grateful to the members of the Berlioz-Emiliani lab for helpful discussions. We thank Damien Bonnard for help with the HTRF assay, Gideon Dreyfuss for the generous gift of the GST-TNPO3 plasmid, and Eric Poeschla for providing us with the SupT1 TL34 cell line. We thank Lisa Hayden for the critical reading of the manuscript. The following reagent was obtained through the AIDS Research and Reference Reagent Program, Division of AIDS, NIAID, NIH from Dr. Robert Craigie: pINSD.His.

\section{Author details}

'Inserm, U1016, Institut Cochin, Paris, France. ${ }^{2}$ CNRS, UMR 8104, Paris, France. ${ }^{3}$ Université Paris Descartes, Paris, France. ${ }^{4}$ LBPA, CNRS, ENS de Cachan, Cachan, France. ${ }^{5}$ Laboratoire MFP, UMR 5234-CNRS, Université de Bordeaux Victor Segalen, Bordeaux, France. ${ }^{6}$ IGBMC (Institut de Génétique et de Biologie Moléculaire et Cellulaire), Département de Biologie et de Génomique Structurales, UDS, CNRS, INSERM, Illkirch, France. ${ }^{7}$ Mutabilis (S.A.), Romainville, France.

\section{Authors' contributions}

$A C, E S, O D, V P$, and $A S$ performed experiments. AC, OD, VP, and $S E$ designed experiments. $A C, O D, V P, R B, M R$ and $S E$ analyzed results. $A C, O D, V P, M R$ and SE wrote the manuscript. All authors read and approved the final manuscript.

\section{Competing interests}

The authors declare that they have no competing interests.

Received: 13 September 2011 Accepted: 16 December 2011 Published: 16 December 2011

\section{References}

1. Fassati A, Goff SP: Characterization of intracellular reverse transcription complexes of human immunodeficiency virus type 1. J Virol 2001, 75:3626-3635

2. Karageorgos L, Li P, Burrell C: Characterization of HIV replication complexes early after cell-to-cell infection. AIDS Res Hum Retroviruses 1993, 9:817-823.

3. Bukrinsky MI, Sharova N, McDonald TL, Pushkarskaya T, Tarpley WG, Stevenson M: Association of integrase, matrix, and reverse transcriptase antigens of human immunodeficiency virus type 1 with viral nucleic acids following acute infection. Proc Natl Acad Sci USA 1993, 90:6125-6129.

4. Farnet $C M$, Haseltine WA: Determination of viral proteins present in the human immunodeficiency virus type 1 preintegration complex. I Virol 1991, 65:1910-1915.

5. Miller MD, Farnet CM, Bushman FD: Human immunodeficiency virus type 1 preintegration complexes: studies of organization and composition. $J$ Virol 1997, 71:5382-5390.

6. Gallay P, Swingler S, Song J, Bushman F, Trono D: HIV nuclear import is governed by the phosphotyrosine-mediated binding of matrix to the core domain of integrase. Cell 1995, 83:569-576.

7. Bushman FD, Fujiwara T, Craigie R: Retroviral DNA integration directed by HIV integration protein in vitro. Science 1990, 249:1555-1558.

8. Ellison V, Abrams H, Roe T, Lifson J, Brown P: Human immunodeficiency virus integration in a cell-free system. J Virol 1990, 64:2711-2715.

9. Farnet $C M$, Haseltine WA: Integration of human immunodeficiency virus type 1 DNA in vitro. Proc Natl Acad Sci USA 1990, 87:4164-4168.

10. Al-Mawsawi LQ, Neamati N: Blocking interactions between HIV-1 integrase and cellular cofactors: an emerging anti-retroviral strategy. Trends Pharmacol Sci 2007, 28:526-535.

11. Turlure F, Devroe E, Silver PA, Engelman A: Human cell proteins and human immunodeficiency virus DNA integration. Front Biosci 2004, 9:3187-3208.

12. Van Maele B, Busschots K, Vandekerckhove L, Christ F, Debyser Z: Cellular co-factors of HIV-1 integration. Trends Biochem Sci 2006, 31:98-105.

13. Cherepanov P, Maertens G, Proost P, Devreese B, Van Beeumen J, Engelborghs Y, De Clerca E, Debyser Z: HIV-1 integrase forms stable tetramers and associates with LEDGF/p75 protein in human cells. J Biol Chem 2003, 278:372-381. 
14. Emiliani S, Mousnier A, Busschots K, Maroun M, Van Maele B, Tempe D, Vandekerckhove L, Moisant F, Ben-Slama L, Witvrouw M, Christ F, Rain JC, Dargemont C, Debyser Z, Benarous R: Integrase mutants defective for interaction with LEDGF/p75 are impaired in chromosome tethering and HIV-1 replication. J Biol Chem 2005, 280:25517-25523.

15. Busschots K, Voet A, De Maeyer M, Rain JC, Emiliani S, Benarous R, Desender L, Debyser Z, Christ F: Identification of the LEDGF/p75 binding site in HIV-1 integrase. J Mol Biol 2007, 365:1480-1492.

16. Cherepanov $P$, Sun $Z Y$, Rahman S, Maertens G, Wagner G, Engelman A: Solution structure of the HIV-1 integrase-binding domain in LEDGF/p75. Nat Struct Mol Biol 2005, 12:526-532.

17. Rahman S, Lu R, Vandegraaff N, Cherepanov P, Engelman A: Structurebased mutagenesis of the integrase-LEDGF/p75 interface uncouples a strict correlation between in vitro protein binding and HIV-1 fitness. Virology 2007, 357:79-90.

18. De Rijck J, Vandekerckhove L, Gijsbers R, Hombrouck A, Hendrix J, Vercammen J, Engelborghs $Y$, Christ F, Debyser Z: Overexpression of the lens epithelium-derived growth factor/p75 integrase binding domain inhibits human immunodeficiency virus replication. J Virol 2006, 80:11498-11509.

19. Llano M, Vanegas M, Hutchins $N$, Thompson D, Delgado S, Poeschla EM: Identification and characterization of the chromatin-binding domains of the HIV-1 integrase interactor LEDGF/p75. J Mol Biol 2006, 360:760-773.

20. Marshall HM, Ronen K, Berry C, Llano M, Sutherland H, Saenz D, Bickmore W, Poeschla E, Bushman FD: Role of PSIP1/LEDGF/p75 in lentiviral infectivity and integration targeting. PLOS ONE 2007, 2:e1340.

21. Shun MC, Raghavendra NK, Vandegraaff N, Daigle JE, Hughes S, Kellam P, Cherepanov P, Engelman A: LEDGF/p75 functions downstream from preintegration complex formation to effect gene-specific HIV-1 integration. Genes Dev 2007, 21:1767-1778.

22. Vandekerckhove L, Christ F, Van Maele B, De Rijck J, Gijsbers R, Van den Haute C, Witvrouw M, Debyser Z: Transient and stable knockdown of the integrase cofactor LEDGF/p75 reveals its role in the replication cycle of human immunodeficiency virus. J Virol 2006, 80:1886-1896.

23. Zielske SP, Stevenson M: Modest but reproducible inhibition of human immunodeficiency virus type 1 infection in macrophages following LEDGFp75 silencing. J Virol 2006, 80:7275-7280.

24. Cherepanov $\mathrm{P}$, Ambrosio AL, Rahman S, Ellenberger T, Engelman A: Structural basis for the recognition between HIV-1 integrase and transcriptional coactivator p75. Proc Natl Acad Sci USA 2005, 102:17308-17313.

25. Hare S, Shun MC, Gupta SS, Valkov E, Engelman A, Cherepanov P: A novel co-crystal structure affords the design of gain-of-function lentiviral integrase mutants in the presence of modified PSIP1/LEDGF/p75. PLOS Pathog 2009, 5:e1000259.

26. Hare S, Di Nunzio F, Labeja A, Wang J, Engelman A, Cherepanov P: Structural basis for functional tetramerization of lentiviral integrase. PLOS Pathog 2009, 5:e1000515.

27. McKee CJ, Kessl JJ, Shkriabai N, Dar MJ, Engelman A, Kvaratskhelia M: Dynamic modulation of HIV-1 integrase structure and function by cellular lens epithelium-derived growth factor (LEDGF) protein. J Biol Chem 2008, 283:31802-31812.

28. Michel F, Crucifix C, Granger F, Eiler S, Mouscadet JF, Korolev S, Agapkina J, Ziganshin R, Gottikh M, Nazabal A, Emiliani S, Benarous R, Moras D, Schultz P, Ruff M: Structural basis for HIV-1 DNA integration in the human genome, role of the LEDGF/P75 cofactor. Embo J 2009, 28:980-991.

29. Gupta K, Diamond T, Hwang Y, Bushman F, Van Duyne GD: Structural properties of HIV integrase. Lens epithelium-derived growth factor oligomers. J Biol Chem 2010, 285:20303-20315.

30. Ciuffi A, Llano M, Poeschla E, Hoffmann C, Leipzig J, Shinn P, Ecker JR, Bushman F: A role for LEDGF/p75 in targeting HIV DNA integration. Nat Med 2005, 11:1287-1289.

31. Engelman A, Cherepanov P: The lentiviral integrase binding protein LEDGF/p75 and HIV-1 replication. PLOS Pathog 2008, 4:e1000046.

32. Poeschla EM: Integrase, LEDGF/p75 and HIV replication. Cell Mol Life Sci 2008, 65:1403-1424.

33. Roe T, Reynolds TC, Yu G, Brown PO: Integration of murine leukemia virus DNA depends on mitosis. Embo J 1993, 12:2099-2108.

34. Weinberg JB, Matthews TJ, Cullen BR, Malim MH: Productive human immunodeficiency virus type 1 (HIV-1) infection of nonproliferating human monocytes. J Exp Med 1991, 174:1477-1482.
35. Siliciano JD, Siliciano RF: Latency and viral persistence in HIV-1 infection. J Clin Invest 2000, 106:823-825.

36. Fassati A: HIV infection of non-dividing cells: a divisive problem. Retrovirology 2006, 3:74.

37. Suzuki Y, Craigie R: The road to chromatin - nuclear entry of retroviruses. Nat Rev Microbiol 2007, 5:187-196.

38. Yamashita M, Emerman M: Retroviral infection of non-dividing cells: old and new perspectives. Virology 2006, 344:88-93.

39. Dismuke DJ, Aiken C: Evidence for a functional link between uncoating of the human immunodeficiency virus type 1 core and nuclear import of the viral preintegration complex. Journal of virology 2006, 80:3712-3720.

40. Yamashita M, Emerman M: The cell cycle independence of HIV infections is not determined by known karyophilic viral elements. PLOS Pathog 2005, 1:e18.

41. Yamashita M, Perez O, Hope TJ, Emerman M: Evidence for direct involvement of the capsid protein in HIV infection of nondividing cells. PLoS Pathog 2007, 3:1502-1510.

42. Arhel NJ, Souquere-Besse $S$, Munier S, Souque P, Guadagnini S, Rutherford S, Prevost MC, Allen TD, Charneau P: HIV-1 DNA Flap formation promotes uncoating of the pre-integration complex at the nuclear pore. Embo J 2007, 26:3025-3037.

43. Gallay P, Hope T, Chin D, Trono D: HIV-1 infection of nondividing cells through the recognition of integrase by the importin/karyopherin pathway. Proc Natl Acad Sci USA 1997, 94:9825-9830

44. Gallay P, Stitt V, Mundy C, Oettinger M, Trono D: Role of the karyopherin pathway in human immunodeficiency virus type 1 nuclear import. J Virol 1996, 70:1027-1032.

45. Popov S, Rexach $M$, Ratner L, Blobel G, Bukrinsky M: Viral protein R regulates docking of the HIV-1 preintegration complex to the nuclear pore complex. J Biol Chem 1998, 273:13347-13352

46. Popov S, Rexach M, Zybarth G, Reiling N, Lee MA, Ratner L, Lane CM, Moore MS, Blobel G, Bukrinsky M: Viral protein $\mathrm{R}$ regulates nuclear import of the HIV-1 pre-integration complex. Embo J 1998, 17:909-917.

47. Vodicka MA, Koepp DM, Silver PA, Emerman M: HIV-1 Vpr interacts with the nuclear transport pathway to promote macrophage infection. Genes Dev 1998, 12:175-185.

48. Ao Z, Huang G, Yao H, Xu Z, Labine M, Cochrane AW, Yao X: Interaction of human immunodeficiency virus type 1 integrase with cellular nuclear import receptor importin 7 and its impact on viral replication. $J$ Biol Chem 2007, 282:13456-13467.

49. Fassati A, Gorlich D, Harrison I, Zaytseva L, Mingot JM: Nuclear import of HIV-1 intracellular reverse transcription complexes is mediated by importin 7. Embo J 2003, 22:3675-3685.

50. Hearps AC, Jans DA: HIV-1 integrase is capable of targeting DNA to the nucleus via an importin alpha/beta-dependent mechanism. Biochem J 2006, 398:475-484.

51. Zaitseva L, Cherepanov P, Leyens L, Wilson SJ, Rasaiyaah J, Fassati A: HIV-1 exploits importin 7 to maximize nuclear import of its DNA genome. Retrovirology 2009, 6:11

52. Zielske SP, Stevenson M: Importin 7 may be dispensable for human immunodeficiency virus type 1 and simian immunodeficiency virus infection of primary macrophages. J Virol 2005, 79:11541-11546.

53. Brass AL, Dykxhoorn DM, Benita Y, Yan N, Engelman A, Xavier RJ, Lieberman J, Elledge SJ: Identification of host proteins required for HIV infection through a functional genomic screen. Science 2008, 319:921-926.

54. Ebina H, Aoki J, Hatta S, Yoshida T, Koyanagi Y: Role of Nup98 in nuclear entry of human immunodeficiency virus type 1 cDNA. Microbes Infect 2004, 6:715-724.

55. Konig R, Zhou Y, Elleder D, Diamond TL, Bonamy GM, Irelan JT, Chiang CY, Tu BP, De Jesus PD, Lilley CE, Seidel S, Opaluch AM, Caldwell JS, Weitzman MD, Kuhen KL, Bandyopadhyay S, Ideker T, Orth AP, Miraglia LJ, Bushman FD, Young JA, Chanda SK: Global analysis of host-pathogen interactions that regulate early-stage HIV-1 replication. Cell 2008, 135:49-60

56. Woodward CL, Prakobwanakit S, Mosessian S, Chow SA: Integrase interacts with nucleoporin NUP153 to mediate the nuclear import of human immunodeficiency virus type 1. J Virol 2009, 83:6522-6533.

57. Zhang R, Mehla R, Chauhan A: Perturbation of host nuclear membrane component RanBP2 impairs the nuclear import of human immunodeficiency virus -1 preintegration complex (DNA). PloS one 2010, 5:e15620. 
58. Allemand E, Dokudovskaya S, Bordonne R, Tazi J: A conserved Drosophila transportin-serine/arginine-rich (SR) protein permits nuclear import of Drosophila SR protein splicing factors and their antagonist repressor splicing factor 1. Mol Biol Cell 2002, 13:2436-2447.

59. Kataoka N, Bachorik JL, Dreyfuss G: Transportin-SR, a nuclear import receptor for SR proteins. J Cell Biol 1999, 145:1145-1152.

60. Lai MC, Lin Rl, Huang SY, Tsai CW, Tarn WY: A human importin-beta family protein, transportin-SR2, interacts with the phosphorylated RS domain of SR proteins. J Biol Chem 2000, 275:7950-7957.

61. Lai MC, Lin RI, Tarn WY: Transportin-SR2 mediates nuclear import of phosphorylated SR proteins. Proc Natl Acad Sci USA 2001, 98:10154-10159.

62. Christ F, Thys W, De Rijck J, Gijsbers R, Albanese A, Arosio D, Emiliani S, Rain JC, Benarous R, Cereseto A, Debyser Z: Transportin-SR2 imports HIV into the nucleus. Curr Biol 2008, 18:1192-1202.

63. Rain JC, Cribier A, Gerard A, Emiliani S, Benarous R: Yeast two-hybrid detection of integrase-host factor interactions. Methods 2009, 47:291-297.

64. Krishnan L, Matreyek KA, Oztop I, Lee K, Tipper CH, Li X, Dar MJ, Kewalramani VN, Engelman A: The requirement for cellular transportin 3 (TNPO3 or TRN-SR2) during infection maps to human immunodeficiency virus type 1 capsid and not integrase. Journal of virology 2010, 84:397-406.

65. Thys W, De Houwer S, Demeulemeester J, Taltynov O, Vancraenenbroeck R, Gerard M, De Rijck J, Gijsbers R, Christ F, Debyser Z: Interplay between HIV entry and transportin-SR2 dependency. Retrovirology 2011, 8:7.

66. Lee K, Ambrose Z, Martin TD, Oztop I, Mulky A, Julias JG, Vandegraaff $N$, Baumann JG, Wang R, Yuen W, Takemura T, Shelton K, Taniuchi I, Li Y, Sodrosky J, Littman DR, Coffin JM, Hughes SH, Unutmaz D, Engelman A, KewalRamani VN: Flexible use of nuclear import pathways by HIV-1. Cell Host Microbe 2010, 7:221-233.

67. Hare S, Gupta SS, Valkov E, Engelman A, Cherepanov P: Retroviral intasome assembly and inhibition of DNA strand transfer. Nature 2010, 464:232-236.

68. Lesbats P, Metifiot M, Calmels C, Baranova S, Nevinsky G, Andreola ML, Parissi V: In vitro initial attachment of HIV-1 integrase to viral ends: control of the DNA specific interaction by the oligomerization state. Nucleic Acids Res 2008, 36:7043-7058.

69. Sinha S, Grandgenett DP: Recombinant human immunodeficiency virus type 1 integrase exhibits a capacity for full-site integration in vitro that is comparable to that of purified preintegration complexes from virusinfected cells. Journal of virology 2005, 79:8208-8216.

70. Sinha S, Pursley MH, Grandgenett DP: Efficient concerted integration by recombinant human immunodeficiency virus type 1 integrase without cellular or viral cofactors. Journal of virology 2002, 76:3105-3113.

71. Llano M, Saenz DT, Meehan A, Wongthida P, Peretz M, Walker WH, Teo W, Poeschla EM: An essential role for LEDGF/p75 in HIV integration. Science 2006, 314:461-464

72. Doitsh G, Cavrois M, Lassen KG, Zepeda O, Yang Z, Santiago ML, Hebbeler AM, Greene WC: Abortive HIV infection mediates CD4 T cell depletion and inflammation in human lymphoid tissue. Cell 2010, 143:789-801.

73. Busschots K, Vercammen J, Emiliani S, Benarous R, Engelborghs Y, Christ F, Debyser Z: The interaction of LEDGF/p75 with integrase is lentivirusspecific and promotes DNA binding. J Biol Chem 2005, 280:17841-17847.

74. Albanese A, Arosio D, Terreni M, Cereseto A: HIV-1 pre-integration complexes selectively target decondensed chromatin in the nuclear periphery. PLoS One 2008, 3:e2413.

75. Arhel N, Genovesio A, Kim KA, Miko S, Perret E, Olivo-Marin JC, Shorte S, Charneau P: Quantitative four-dimensional tracking of cytoplasmic and nuclear HIV-1 complexes. Nat Methods 2006, 3:817-824.

76. Lu R, Limon A, Devroe E, Silver PA, Cherepanov P, Engelman A: Class II integrase mutants with changes in putative nuclear localization signals are primarily blocked at a postnuclear entry step of human immunodeficiency virus type 1 replication. J Virol 2004, 78:12735-12746.

77. Riviere L, Darlix $J$, Cimarelli A: Analysis of the viral elements required in the nuclear import of HIV-1 DNA. Journal of virology 2010, 84:729-739.

78. Zhou L, Sokolskaja E, Jolly C, James W, Cowley SA, Fassati A: Transportin 3 Promotes a Nuclear Maturation Step Required for Efficient HIV-1 Integration. PLoS pathogens 2011, 7:e1002194.

79. Ocwieja KE, Brady TL, Ronen K, Huegel A, Roth SL, Schaller T, James LC, Towers GJ, Young JA, Chanda SK, Konig R, Malani N, Berry CC, Bushman FD: HIV Integration Targeting: A Pathway Involving Transportin-3 and the Nuclear Pore Protein RanBP2. PLoS pathogens 2011, 7:e1001313.
80. Wu X, Liu H, Xiao H, Conway JA, Hehl E, Kalpana GV, Prasad V, Kappes JC: Human immunodeficiency virus type 1 integrase protein promotes reverse transcription through specific interactions with the nucleoprotein reverse transcription complex. Journal of virology 1999, 73:2126-2135.

81. Hehl EA, Joshi P, Kalpana GV, Prasad VR: Interaction between human immunodeficiency virus type 1 reverse transcriptase and integrase proteins. Journal of virology 2004, 78:5056-5067.

82. Briones MS, Dobard CW, Chow SA: Role of human immunodeficiency virus type 1 integrase in uncoating of the viral core. Journal of virology 2010, 84:5181-5190.

83. Bushman FD, Engelman A, Palmer I, Wingfield P, Craigie R: Domains of the integrase protein of human immunodeficiency virus type 1 responsible for polynucleotidyl transfer and zinc binding. Proceedings of the National Academy of Sciences of the United States of America 1993, 90:3428-3432.

84. Craigie R, Hickman AB, Engelman A: Integrase. HIV Volume 2: A Practical Approach Oxford Univ Press; 1995, 53-71.

85. Cherepanov P: LEDGF/p75 interacts with divergent lentiviral integrases and modulates their enzymatic activity in vitro. Nucleic Acids Res 2007, 35:113-124.

86. Leh H, Brodin P, Bischerour J, Deprez E, Tauc P, Brochon JC, LeCam E, Coulaud D, Auclair C, Mouscadet JF: Determinants of Mg2+-dependent activities of recombinant human immunodeficiency virus type 1 integrase. Biochemistry 2000, 39:9285-9294.

87. Maroun M, Delelis O, Coadou G, Bader T, Segeral E, Mbemba G, Petit C, Sonigo P, Rain JC, Mouscadet JF, Benarous R, Emiliani S: Inhibition of early steps of HIV-1 replication by SNF5/Ini1. J Biol Chem 2006, 281:22736-22743

88. Brussel $A$, Sonigo $P$ : Analysis of early human immunodeficiency virus type 1 DNA synthesis by use of a new sensitive assay for quantifying integrated provirus. J Virol 2003, 77:10119-10124.

89. Wang JY, Ling H, Yang W, Craigie R: Structure of a two-domain fragment of HIV-1 integrase: implications for domain organization in the intact protein. Embo J 2001, 20:7333-7343

doi:10.1186/1742-4690-8-104

Cite this article as: Cribier et al: Mutations affecting interaction of integrase with TNPO3 do not prevent HIV-1 CDNA nuclear import. Retrovirology 2011 8:104.

\section{Submit your next manuscript to BioMed Central and take full advantage of:}

- Convenient online submission

- Thorough peer review

- No space constraints or color figure charges

- Immediate publication on acceptance

- Inclusion in PubMed, CAS, Scopus and Google Scholar

- Research which is freely available for redistribution

Submit your manuscript at www.biomedcentral.com/submit
C BioMed Central 